How to cite: Rîndaşu-Beuran, I.S., Ciurea, A.L., Dumitrache, R., Ion, B., Achim, D., Mazilu, P., Bogzianu, R.D. (2019) Flood Risk Assessment in the Tisa River Basin. 2019 "Air and Water - Components of the Environment" Conference Proceedings, Cluj-Napoca, Romania, p. 137-150, DOI: 10.24193/AWC2019 14.

\title{
FLOOD RISK ASSESSMENT IN THE TISA RIVER BASIN
}

\author{
Ionel Sorin RÎNDAŞU-BEURAN ${ }^{I}$ 凹, Anemari Luciana CIUREA ${ }^{1}$, Ramona \\ DUMITRACHE ${ }^{2}$, Bogdan ION ${ }^{2}$, Diana ACHIM ${ }^{2}$, Petrișor MAZILU ${ }^{I}$, \\ Răzvan Dan BOGZIANU ${ }^{I}$
}

DOI: 10.24193/AWC2019 14

\begin{abstract}
This paper presents an assessment of the flood risk at Tisa basin level resulted from the activity developed into the Jointisza project and based on the national reporting documents for the 2007/60 EU Directive on assessment and management of flood risk. In the first part, a short presentation about the flood hazard and it management in Romania and flood protection infrastructures from the Romanian part of the Tisa river basin are offered. The used data and methods for identification/selection of significant historical floods, the elaboration of hazard maps at the Tisa river basin, the elaboration of flood risk maps and the methodology used for climate change impact estimation on flood risk are presented. In the second part of paper the significant historical floods and areas with important flood risk in Tisa river basin were identified. Also, the national flood hazard maps and flood risk maps for Tisa river basin, potential adverse consequences and climate change impact estimation on flood risk were presented.
\end{abstract}

Keywords: Tisa River basin, historical floods, flood risk management.

\section{INTRODUCTION}

\subsection{Flood hazard and it management in Romania}

Floods are the main hazard in Romania, which through intensity and amplitude threaten population, economic activity, environment and cultural heritage. The floods are possible throughout the year, having as a source natural overflow of river stretches, heavy rainfalls, snow melting, blockages due to ice bridges or floats etc.

Over time, there have been several forms of addressing the phenomenon, from the notion of flood "fighting", to the notion of flood "defence" and then to flood management. The new flood risk management approach is coordinated by all responsible actors and involves awareness and involvement of human communities in avoiding loss of life and reducing damage.

World practice has shown that floods cannot be avoided, but they can be managed, and their effects can be reduced through a systematic process,

\footnotetext{
1 "Romanian Waters" National Administration, Bucharest, e-mail: sorin.randasu@ rowater.ro, anemari.ciurea@ rowater.ro, petrisor.mazilu@ rowater.ro, razvan.bogzianu@ rowater.ro .

2 National Institute of Hydrology and Water Management, Bucharest, e-mail: ramona.dumitrache@hidro.ro, bogdan.ion@hidro.ro, diana.achim@hidro.ro
} 
represented by measures and actions designed to help reduce the flood risk associated with these phenomena.

Flood risk management means applying policies, procedures and practices to identify risks, analyse and evaluate them, treat, monitor and re-evaluate risks in order to reduce them, so that human communities, all citizens can live, work and satisfy their needs and aspirations in a sustainable physical and social environment.

Flood risk management in Romania is provided by the Ministry of Waters and Forests, at central level; the National Administration "Romanian Waters" (NARW) through 11 river basin authorities at the catchment level and the National Institute of Hydrology and Water Management (NIHWM) which offers the scientific support and methodological guidance needed for implementation of European Directives at national level.

Also, it is provided by the Ministry of Internal Affairs, the General Inspectorate for Emergency Situations which intervene through its 41 county branches in case of emergency situations, the Local and County Committees for emergency situations.

The Management of Emergency Situations is ensured by the components of the National Emergency Situations Management System, according to the provisions of Emergency Ordinance of the Romanian Government no. 1/2014 regarding certain measures in the field of emergency situations management, as well as for amending and supplementing the Government Emergency Ordinance no. 21/2004 regarding the National Emergency Situations Management System.

Also, of the law 15/2005 for the approval of Government Emergency Ordinance no. 21/2004 with subsequent amendments and completions, as well as of the Joint Order of the Ministry of Administration and Interior and of the Ministry of Environment and Forests no. 1422/192/2012 for the approval of the "Regulation on management of emergency situations caused by floods, dangerous meteorological phenomena, hydraulic accidents, accidental water pollutions and marine pollutions in the coastal area".

The principles of emergency situations management are: forecasting and prevention, the priority protecting and saving of human life, respect for human rights and fundamental freedoms, assuming the responsibility of emergency management by public administration authorities, cooperation at national, regional and international level with similar bodies and organizations.

Also, the transparency of activities carried out for emergencies so that they do not lead to worsening of the effects produced, the continuity and gradual of the emergency management activities, from the level of the local public administration authorities to the level of the central public administration authorities, depending on their magnitude and intensity, operability, active cooperation and hierarchical subordination of the components of the National System.

\subsection{Flood protection infrastructures from the Romanian part of the Tisa river basin}

In the Romanian part of the Tisa river basin as flood protection infrastructures are the following: embankment works (with a total length of 3,634.778 km), 138 permanent reservoirs with a total attenuation volume of $391.486 \mathrm{mil}^{3}, 87$ 
temporary reservoirs with a total volume of 199.623 mil.m ${ }^{3}$ and 19 polders with a

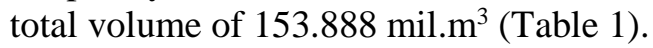

Table 1. Flood protection infrastructure at Tisa's subbasins in Romania

\begin{tabular}{|c|c|c|c|c|c|c|c|c|c|c|c|c|c|}
\hline 2 & 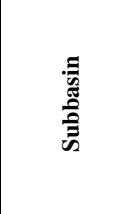 & 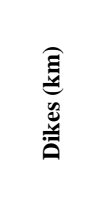 & 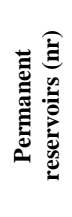 & 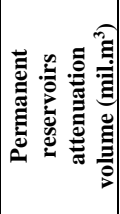 & 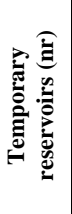 & 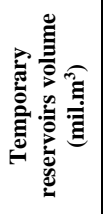 & 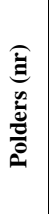 & 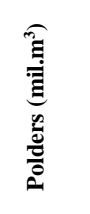 & 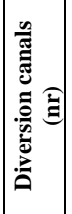 & 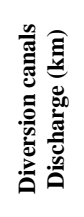 & 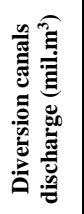 & 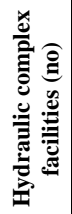 & 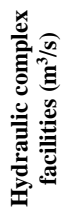 \\
\hline 1 & $\mathrm{Sc}$ & & & & & & & & & & & 0 & \\
\hline \begin{tabular}{|l|}
2 \\
\end{tabular} & Crișuri & 1334.0 & 37 & 97.404 & 58 & 84 & 13 & 24.475 & 21 & 376 & 335 . & $\underline{0}$ & \\
\hline \begin{tabular}{|l|}
3 \\
\end{tabular} & Mur & 87 & 19 & 11 & 阷 & 72. & 2 & 19.4 & 12 & 160. & 9. & 5 & 64.3 \\
\hline & Bane & 5 & 10 & & 12 & 27 & 1 & 4 & 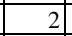 & 15. & 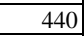 & 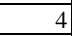 & 650.5 \\
\hline $\overrightarrow{\Gamma o}$ & tal & 634.778 & 138 & 391.486 & 87 & 199.623 & 19 & 153.888 & 52 & 621.71 & 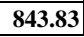 & 9 & 714.8 \\
\hline
\end{tabular}

Also, $621.71 \mathrm{~km}$ of diversion canals with a derived discharge of $843.83 \mathrm{mil}^{3} \mathrm{~m}^{3}$ and 9 hydraulic complex facilities with a total maximum discharge of $714.8 \mathrm{mil} . \mathrm{m}^{3}$ are presents. Practically, a very extended drainage system is functional in Tisa river basin (Table 2).

Table 2. The drainage system in the Tisa river basin

\begin{tabular}{|c|l|c|}
\hline No. & \multicolumn{1}{|c|}{ Sub-basin } & Area (ha) \\
\hline 1 & Someș-Tisa -13 systems & 1828.18 \\
\hline 2 & Crișuri -30 systems & 3257.83 \\
\hline 3 & Mureș - 16 systems & 928.88 \\
\hline 4 & Banat -12 systems & 2025.73 \\
\hline & Total & $\mathbf{8 0 4 0 . 6 2}$ \\
\hline
\end{tabular}

\section{DATA AND METHODS}

\subsection{Used data}

The data used in this document were statistical, hydrological, topographical, geographical, land use and GIS provided by the NIHWM and NARW and those resulted from other projects (e.g. National Programme for Prevention, Protection and Reduction of Flood Effects - PPPDEI) and elaborated reports during the implementation of the 2007/60/EC Directive.

\subsection{Methods}

On the surface of the Tisa River Basin, floods were recorded in all seasons of the year, but the most significant are formed in the winter, spring and summer season.

The identification/selection of significant historical floods was made considering the hydrological criteria (to identify significant floods in terms of hazard) but also the extent of their effects (criteria for identifying significant historical floods in terms of 
damage). The criteria for the number of victims and the economic ones (number of homes, $\mathrm{km}$ of affected roads) were considered as priority.

Areas with Significant Potentially Flood Risk (A.P.S.F.R.) were defined after consulting the information available at the moment, within the Projects Prevention and protection against floods, dangerous meteorological phenomena, hydraulic accidents and accidental pollutions and the results of PHARE 2005/017 690.01.01 Contributions to the development of the flood risk management strategy. At the same time, has been taken into account the flood-protected areas with hydraulic works, considering all the floods that have occurred in the past and which had a significant negative impact, without removing from that list those floods that can occur on sectors that have been hydraulically improved.

Hazard maps at the Tisa basin reported at European Commission have been prepared in accordance with the requirements of the Floods Directive for areas designated as having a significant flood risk. The hazard map cover the geographical areas that may be flooded in the scenarios:

- low probability scenario (Q $0.1 \%$ - floods that can occur once every 1000 years);

- medium probability scenario (Q $1 \%$ - floods that can occur once every 100 years);

- high probability scenario (Q 10\% - floods that can occur once every 10 years)

The results obtained in the Plan for prevention, protection and mitigation of the floods effects, were mostly, used to make hazard maps.

The method used for the elaboration of hazard maps at the Tisa river basin, within the Plan for prevention, protection and mitigation of the floods effects National Programme (during the period 2011-2014), is based on complex studies and contains two components: I) topographic and geodetic studies, and II) hydrological and hydraulic studies.

- $\quad$ as a result of topographic and geodetic studies a DTM has been obtained which has a very high resolution $( \pm 10-15 \mathrm{~cm}$ vertically - A Level detail) for the area considered as a priority and a high resolution $( \pm 15-20 \mathrm{~m}$ vertically - B Level detail) and corresponds to the LIDAR method, complemented with classical topographical measurements for engineering structures on water courses (bridges, small bridges, defence works etc.), and for the rest of the river basin DTM has been obtained based on vectorization available topographic maps (C level detail);

- hydrological modelling consisted in calculating the hydrographs of flows on the rivers basins, propagation and composition thereof on the main rivers and tributaries. The hydrological models CONSUL and RAZVAN have been using which have been elaborated within National Institute of Hydrology and Water Management. The hydraulic modelling of the water courses identified as flood potential consisted in one-dimensional (1D) simulation of flow with HEC-Ras 4.1.0 software and two-dimensional (2D) with the SMS HYDRO_AS - 2D software under the current conditions of river basin management.

Flood risk maps are made based on a methodology developed within the National Institute of Hydrology and Water Management for each probability of exceeding the maximum flow rate of: $0,1 \%, 1 \%$ and $10 \%$, according to law, for the following indicators: 
- the approximate number of affected inhabitants (for which the statistical method was used);

- indicators, related to the other types of consequences - economic, environment, cultural heritage.

A risk matrix has been elaborated and applied which takes into account various layers of information from CLC and NAVTEQ for indicators related to economic consequences, for the elaboration of flood risk maps.

For each depth class, the magnitude of the hazard is evaluated, assigning three classes with the following meanings: class 1 - less than $0.5 \mathrm{~m}$; class $2-0,5-1.5 \mathrm{~m}$; class 3 - more than $1.5 \mathrm{~m}$, resulting three areas: major risk areas - in red, medium risk areas - in orange, low risk areas - in yellow.

The methodology used for climate change impact estimation on flood risk is based on the following steps:

- Hydrological model selection:

The CONSUL hydrological model was used, which allows simulation of discharge hydrographs on sub-basins, their routing and composition on the main river and tributaries, and attenuation by reservoirs. Generally, the CONSUL model was used for flow simulation and forecasting (Leonte-Neagu et al., 1997; Stănescu et al., 1997; Mic et al., 2006; Stanciu et al., 2005) and represent a valid tool for assessing the impact of climate change on water resources in a river basin (Corbuș et al., 2011; Corbuș et al., 2012; Corbuș et al., 2013; Corbuş et al., 2014).

- Calibration of the hydrological model:

For the calibration of the CONSUL model parameters, corresponding to the hydrometric stations located in the closing sections of the river sub-basins, the largest rainfall-runoff events from the historical period were simulated, covering a wide range of possible situations in case of floods formation.

- $\quad$ Setting the Climate Change Scenario.

Climate evolution simulations obtained using meteorological models have been used.

1. Flow simulation over the long period using the hydrological model

The calibrated hydrological model allowed the long-term simulation of discharge hydrographs at 6-hours' time step for both the reference period 19712000 and the future period 2021-2050.

2. Analysis of the results. The discharge series resulting from the two longterm simulations were analyzed comparatively in order to estimate the effects of climate change on maximum discharges.

\section{RESULTS}

3.1. Significant historical floods and areas with important flood risk in Tisa river basin identified

Among the most known floods is mentioned those from: 1912, 1932, 1941, 1966, 1970, 1974, 1975, 1978, 1979, 1980, 1981, 1989, 1993, 1995, 1996, 1997, 2001, 2005, 2006, 2008 and 2010. 
In 1970, important floods have occurred that had as a triggering factor a heavy rain regime, recording significant water flows in almost all the big watercourses in Romania.

The maximum recorded flows had values of: $576 \mathrm{~m} 3 / \mathrm{s}$ at the Oradea gauging station on the Crișul Repede River, $626 \mathrm{~m}^{3} / \mathrm{s}$ at the Tinca gauging station and $517 \mathrm{~m}^{3} / \mathrm{s}$ at the Zerind gauging station both on the Crişul Negru river, $466 \mathrm{~m}^{3} / \mathrm{s}$ at the Bocsig gauging station on the Crişul Alb River, 1,580 m³ $/ \mathrm{s}$ in Ocna Mureş, 2,450 $\mathrm{m}^{3} / \mathrm{s}$ in Alba Iulia, 2,320 $\mathrm{m}^{3} / \mathrm{s}$ in Arad and $700 \mathrm{~m}^{3} / \mathrm{s}$ in Topa (on the Târnava Mare river).

The main cause of flood formation in 1975 was the extremely heavy rainfall from July 1 to July 3 on a high percentage of saturation soil.

At short intervals, precipitation was sometimes extremely torrential, with 2.5 $\mathrm{mm} / \mathrm{min}$ in Odorheiul Secuiesc town.

The maximum recorded flows had values of: $900 \mathrm{~m}^{3} / \mathrm{s}$ in Mediaș, $851 \mathrm{~m}^{3} / \mathrm{s}$ in Blaj, $630 \mathrm{~m}^{3} / \mathrm{s}$ in Târnăveni and $950 \mathrm{~m}^{3} / \mathrm{s}$ in Turda.

The floods formed between December 1995 and January 1996 resulted in the rapid warming and melting of the snow layer, an event overlaid with significant liquid precipitations falling under a frozen soil, unable to allow infiltration, and runoff on the slopes into the riverbeds.

The probability of exceeding the maximum flows was between 5 and $30 \%$ on the rivers in Maramureș county and the Someș river basin.

The maximum recorded flows had values of: $605 \mathrm{~m}^{3} / \mathrm{s}$ at the Chişineu Criş gauging station on the Crișul Alb river, $548 \mathrm{~m}^{3} / \mathrm{s}$ at Zerind on the Crişul Negru river, $1,125 \mathrm{~m}^{3} / \mathrm{s}$ at Glodeni gauging station on the Mureș river, Alba-Iulia - 1,247 $\mathrm{m}^{3} / \mathrm{s}$ and $\operatorname{Arad}-1,046 \mathrm{~m}^{3} / \mathrm{s}$.

On the Arieş river the maximum flow was recorded at Baia de Arieş gauging station $-805 \mathrm{~m}^{3} / \mathrm{s}$.

In 2006, there were floods that had the effect of exceeding the defence level, at the gauging station Cristeştii Ciceului on the Ilişua river having a maximum flow of $212 \mathrm{~m} 3 / \mathrm{s}$, resulting in 13 losses of human lives and large material damage.

In the hydrological and in the extent of it effects criteria, 39 significant historical events were selected at the Tisa basin (Tisa and its tributaries with catchment over $1000 \mathrm{~km}^{2}$ ) for the period from 1970 to 2010 presented below (Fig. 1).

1. May 1970 on: Tisa r. - downstream loc. Bocicoiu Mare, upstream loc. Teceu Mic, Vişeu r. - downstream confl. Ţâsla r., Iza r. - downstream loc. Săcel, Tur r., Someş r. - downstream confl. Şieu, r. Lăpuş - downstream confl. Suciu;

Also, Crasna r. - Ier r., Mureș r. - downstream loc. Neagra, Târnava r. downstream loc. Sub Cetate, Târnava Mică r. - downstream loc. Praid, Strei r. downstream confl. Crivadia upstream loc. Călan;

2. July 1975 on: Mureș r. - downstream loc. Glodeni, Arieş r. - downstream loc. Albac, Târnava r. - downstream loc. Cristuru Secuiesc, Târnava Mică r.downstream loc. Praid, Strei r. - loc. Ohaba de Sub Piatră and Sălaş;

3. July 1980 on: Crişul Negru r. - downstream confl. Criştior, Crişul Repede r. - downstream loc. Izvoru Crişului, Barcău r. - downstream confl. Valea Mare;

4. December 1995 on: Crişul Alb r. - downstream loc. Criş, upstream Ţipar temporary reservoir; 
5. June 1997 on: Barcău r. - downstream loc. Marca, Ier r. - loc. Săcueni;

6. June 1998 on: Mureș r. - downstream confl. Arieş, Târnava r. - downstream confl. Vişa, Târnava Mică r. - downstream loc. Crăieşti, Sebeş r. - downstream confl. Dobra and r. Secaş, Strei r. - downstream confl. Crivadia;

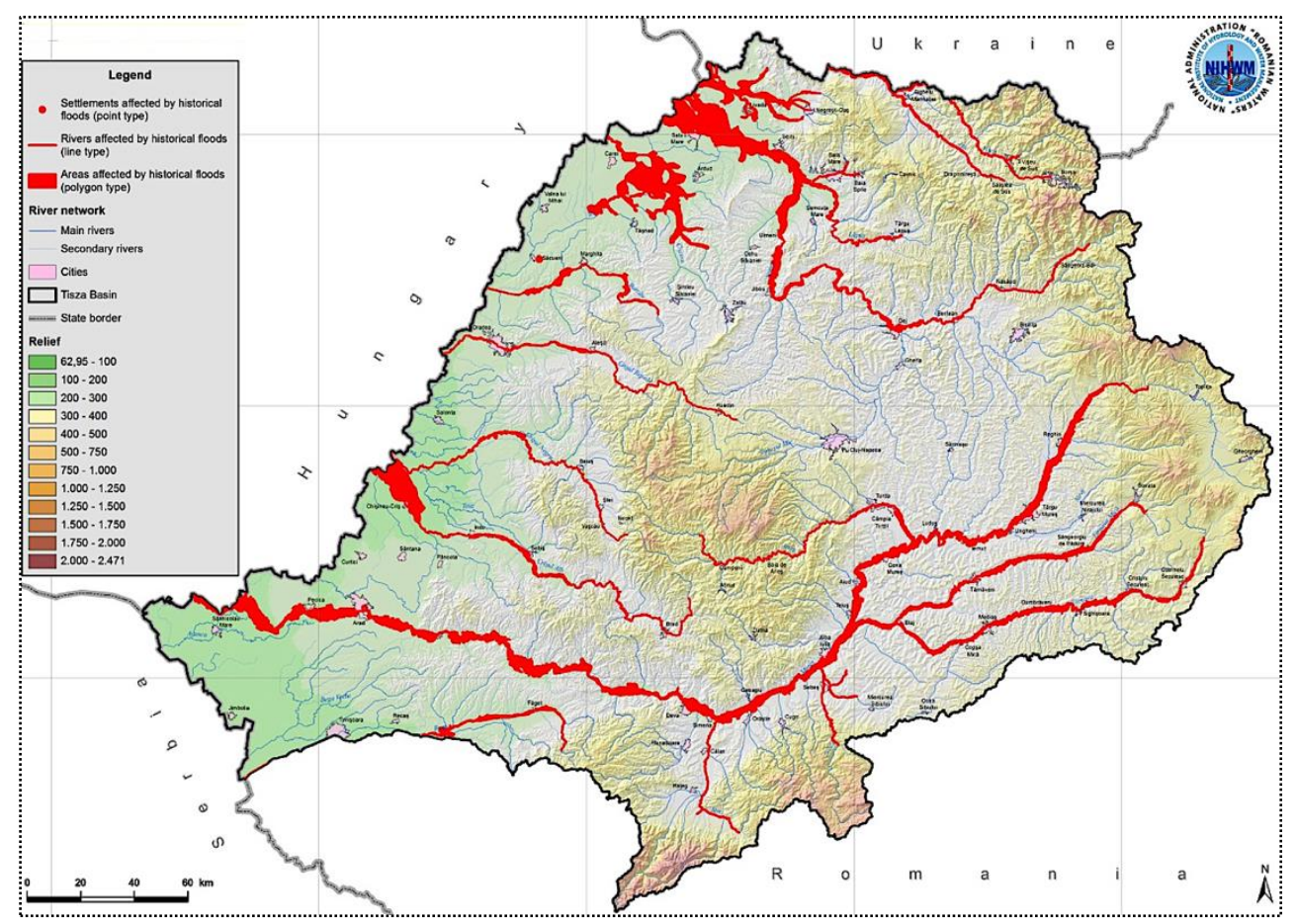

Fig. 1. Map with significant historical floods in Tisa River Basin in Romania.

7. April 2000 on: Crişul Alb r. - downstream loc. Mihăileni, Crişul Negru r. downstream loc. Poiana, Bega r. - downstream loc. Luncanii de Jos, upstream loc. Topolovăţu Mare;

8. March 2001 on: Tisa r. - downstream loc. Bocicoiu Mare, upstream loc. Teceu Mic, Vişeu r. - downstream confl. Vaser and r. Vaser, Iza r. - downstream Confl. Boicu;

Also, Someş r. - sector loc. Şanţ Valea Luncii, Lăpuș r. - downstream confl. r. Craica and tributaries Săsar, Firiza;

9. April 2005 on: Bega r. - downstream loc. Luncanii de Jos, upstream loc. Topolovăţu Mare;

10. July 2008 on: Tisa r. - downstream loc. Bocicoiu Mare, Vişeu r. downstream confl. Ţâsla r., Iza r. - downstream loc. Dragomireşti.

A situation about areas with significant potentially flood risk related to the Tisa River and its tributaries with a catchment size over $1.000 \mathrm{~km}^{2}$ at Tisa River Basin level in Romania is showed in Table 3 and in the Fig. 2. 
Table 3. Areas with Significant Potentially Flood Risk

\begin{tabular}{|c|c|}
\hline Nr. crt. & A.P.S.F.R. name \\
\hline 1 & Tisa r.- downstream loc. Bocicoiu Mare \\
\hline 2 & Vişeu r. - downstream confl. r. Țâsla \\
\hline 3 & Iza r. - downstream loc. Săcel \\
\hline 4 & Tur r. - downstream loc. Negreşti-Oaş \\
\hline 5 & Someş r. - downstream loc. Şanţ, upstream loc. Roşiori \\
\hline 6 & Someş r. - downstream loc. Roşiori \\
\hline 7 & Şieu r. \\
\hline 8 & Someşul Mic r. - downstream loc. Floreşti \\
\hline 9 & Lăpuş r. - downstream confl. r. Suciu \\
\hline 10 & Crasna r. - upstream loc. Vârşolţ \\
\hline 11 & Crasna r. - downstream loc. Vârşolţ, upstream loc. Acâş \\
\hline 12 & Crasna r. - downstream loc. Acâş, upstream loc. Moftinu Mare \\
\hline 13 & Crasna r. - downstream loc. Moftinu Mare \\
\hline 14 & Ier r. - downstream loc. Mihăieni \\
\hline 15 & Crișul Alb r. - downstream confl. Valea Satului \\
\hline 16 & Crișul Negru r. - downstream loc. Poiana \\
\hline 17 & Crișul Repede r. - downstream confl. r. Șipot \\
\hline 18 & Barcău r. - downstream loc. Subcetate \\
\hline 19 & Ier r. - downstream loc. Unimăt, upstream confl. r. Checheţ \\
\hline 20 & Mureș r. - downstream loc. Neagra \\
\hline 21 & Arieș r. - downstream loc. Albac \\
\hline 22 & Târnava Mică r. - downstream loc. Praid \\
\hline 23 & Târnava r. - downstream loc. Sub Cetate \\
\hline 24 & Sebeş r. - downstream Confl. Dobra \\
\hline 25 & Strei r. - downstream Loc. Petros \\
\hline 26 & Bega r. - downstream loc. Luncanii de Jos, upstream confl. Iosifalău \\
\hline 27 & Bega r. - downstream loc. Topolovăţul Mic \\
\hline 28 & Bega Veche r. - loc. Sânandrei \\
\hline 29 & Bega Veche r. - downstream loc. Săcălaz \\
\hline
\end{tabular}

\subsection{National flood hazard maps and flood risk maps for Tisa river basin}

For the Tisa river and its tributaries with catchment over $1.000 \mathrm{~km} 2$ hazard maps were made in the Plan for prevention, protection and mitigation of the floods effects for 24 areas with a total length of about $2.975 \mathrm{~km}$, declared as potentially significant flood risk areas (Fig. 3).

The hazard maps were verified and corrected, harmonized and structured unitary, codified according to WISE and then transmitted to the EC.

Moreover, for five areas reported to the European Commission and not covered by the Plan for prevention, protection and mitigation of the floods effects, flood curves were generated based on simplified approximate methods (modelling with fuzzy systems - GrassGIS, tools that use ArcView extensions, approximate 
hydraulic modelling with HEC-RAS etc.) over a length of about $369 \mathrm{~km}$, these areas will be modelled in detail until the next reporting stage.

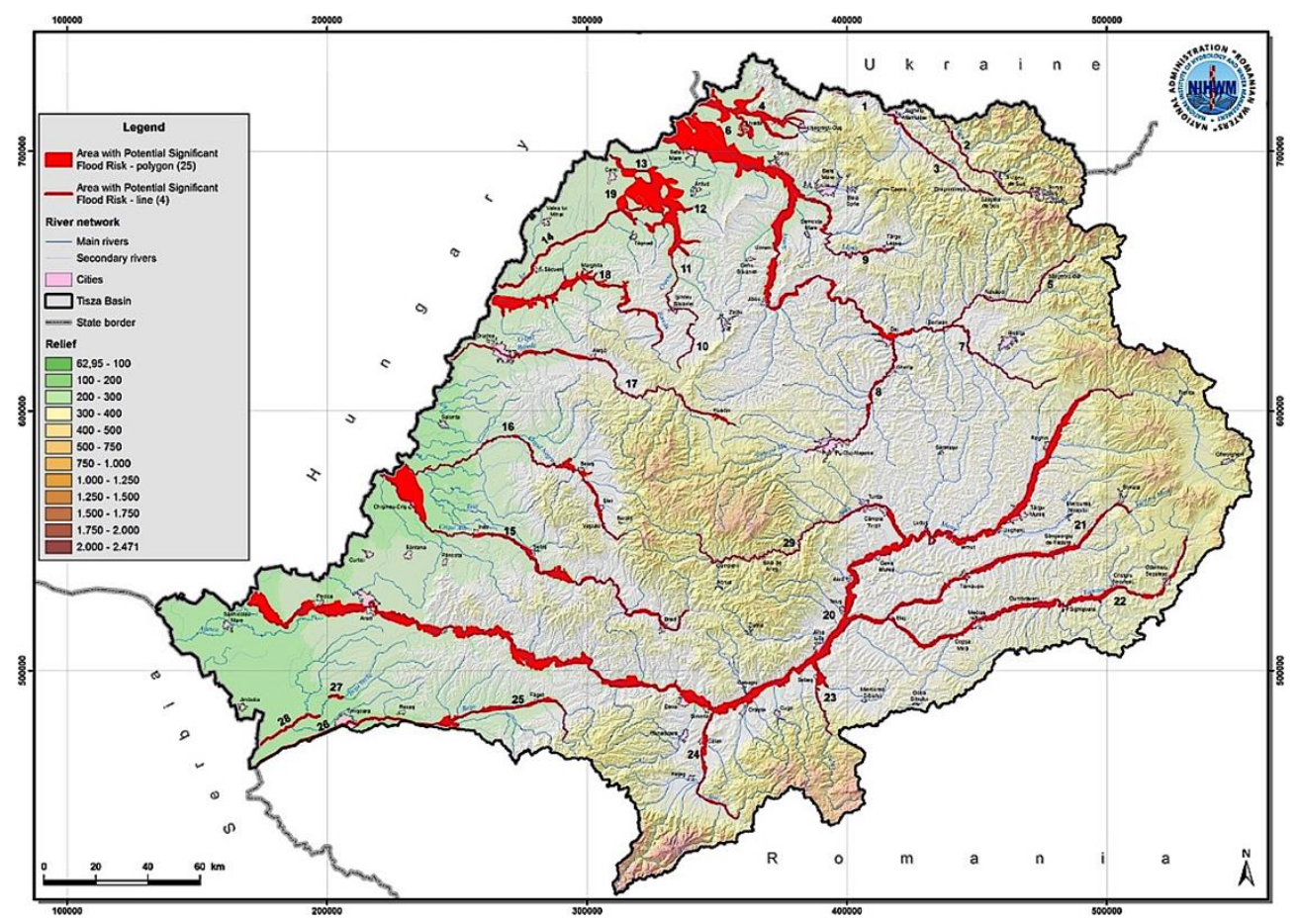

Fig. 2. Map with A.P.S.F.R. in Tisa River Basin in Romania. The A.P.S.F.R. name is according to Table 3.

A qualitative assessment of flood risk was chosen; this assumed, first, identification of risk receptors and then assessing the vulnerability of the identified and exposed flood risks objectives, taking into account the depth of water and potential damage to flooded objectives, respectively the impact on the risk receptor considered (Fig. 4).

Figures 3 and 4 present hazard maps and flood risk maps (average scenario $1 \%$ ) for the Tisa river and its tributaries with catchment over $1.000 \mathrm{~km}^{2}$ in Romania.

Flood hazard and flood risk maps published on the National Administration Romanian Waters and reported to EC are made for the probability of exceeding the maximum flow rate of $1 \%$ (average overrun probability) covering about $3126 \mathrm{~km}$ of watercourses at the Tisa river and its tributaries with catchment over $1000 \mathrm{~km}^{2}$.

Subsequently, maps developed in the other two scenarios: $0.1 \%$ (low probability of exceedance) and 10\% (high probability of exceedance), according to law were published, but these covers only the areas for which flood hazard maps were available within the Plan for prevention, protection and mitigation of the floods effects $\left(2975 \mathrm{~km}\right.$ - for Tisa river and its tributaries with catchment over $\left.1000 \mathrm{~km}^{2}\right)$. 


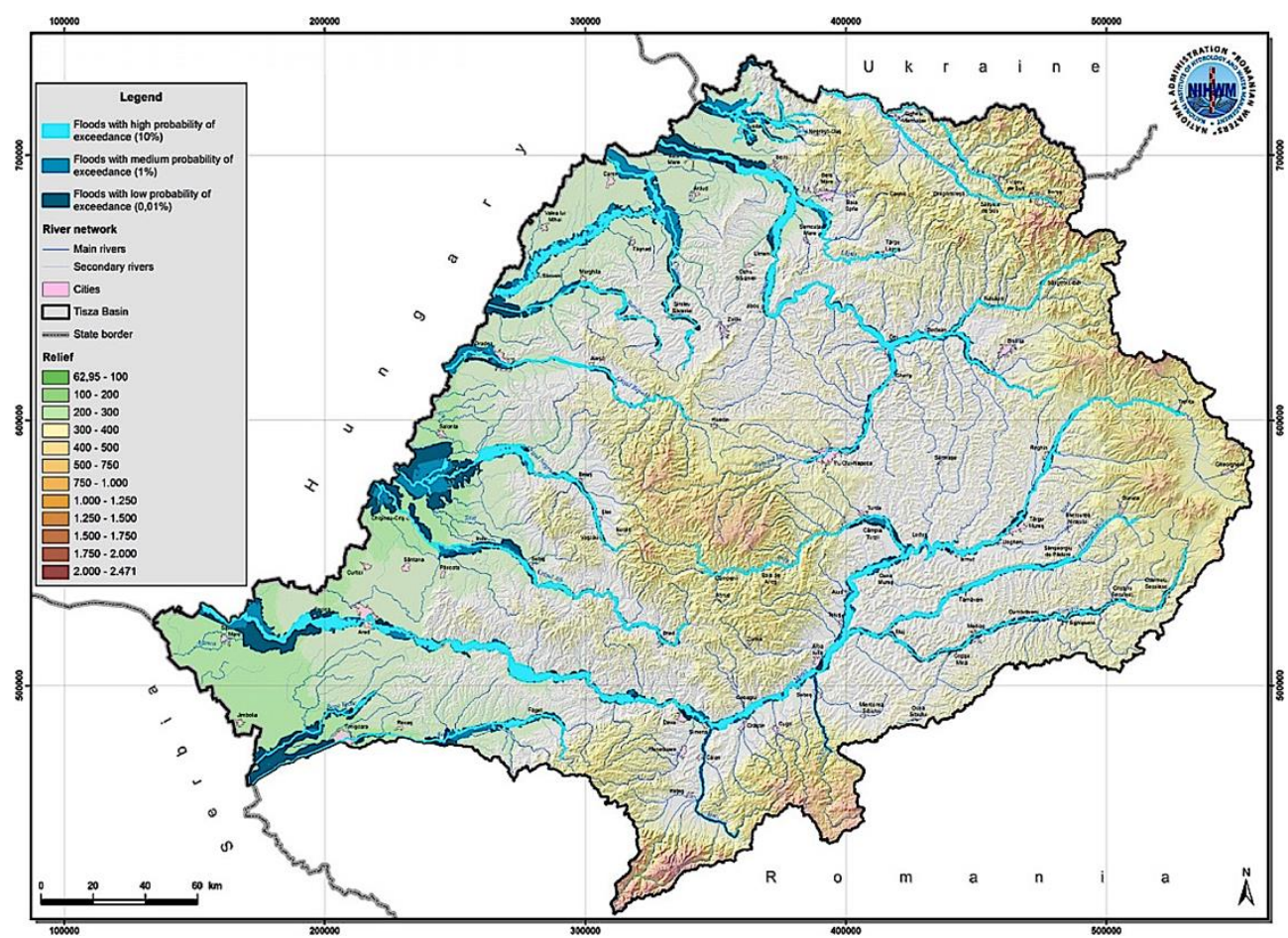

Fig. 3. Flood hazard map of Tisa River Basin in Romania.

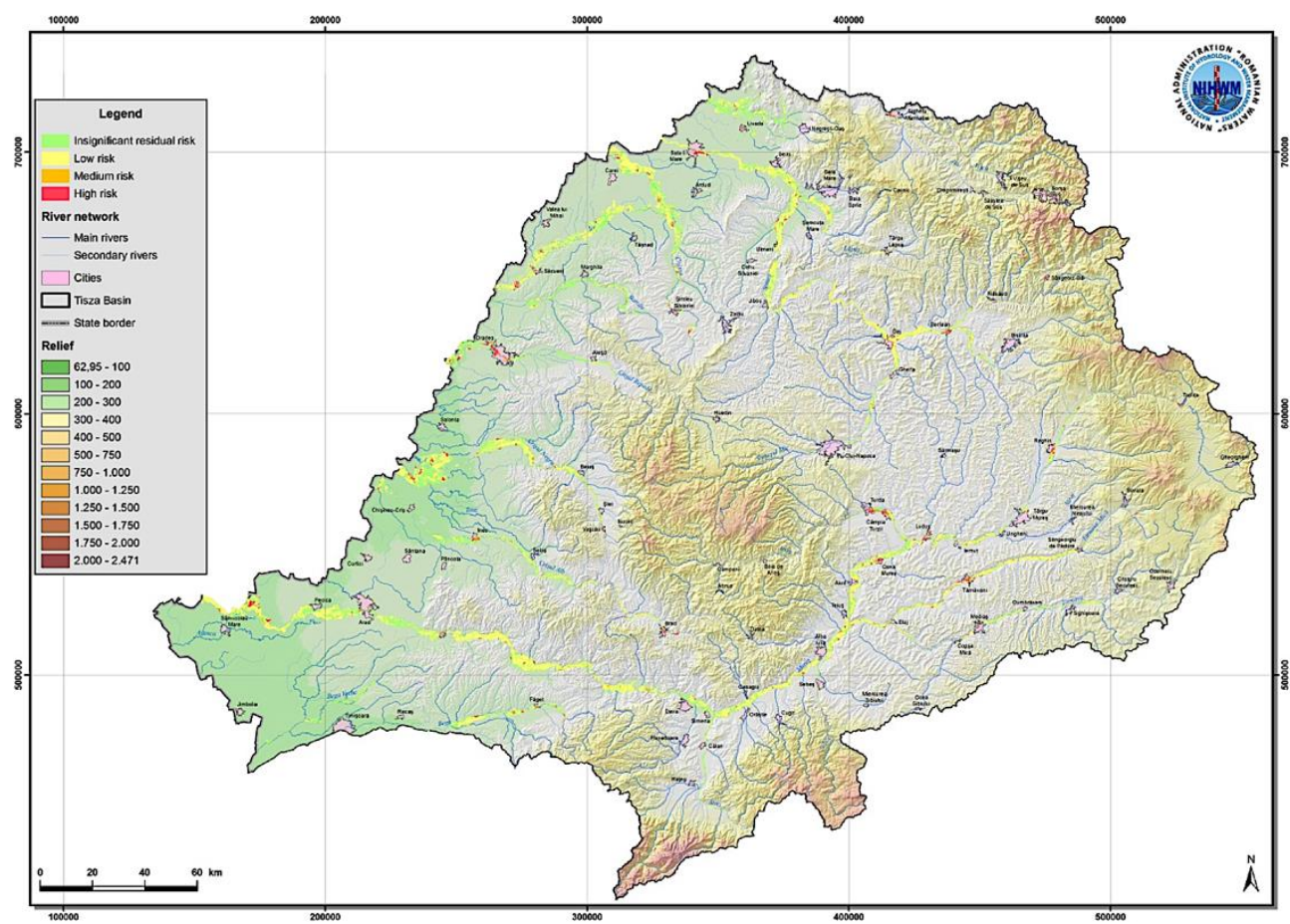

Fig. 4. Flood risk map of Tisa River Basin in Romania. 


\section{DISCUSSIONS}

\subsection{Potential adverse consequences}

Based on hazard and flood risk maps a statistical analysis has been developed a statistical analysis based on the results from the application of the average scenario, respectively events with medium probability (every 100 years).

One of the most susceptible categories to flooding is the population. In the case of Tisa river basin on the territory of Romania (for Tisa river and its tributaries with catchment over $1000 \mathrm{~km}^{2}$ ), about 376,252 inhabitants are at risk of flooding.

Also, a number of key indicators have been calculated which describing the main consequences that floods can have on the environment, such as IED installations, protected areas (national, SCI, SPA, Habitats, Protected Areas for water capture for human consumption etc.), but also other indicators that can describe the potential adverse effects on the environment.

Thus, they resulted as follows: 17 IED installations, protected areas that are located in floodable areas of which: 66 protected areas for water capture for human consumption, 40 SPA, 46 SCI.

Infrastructure is an important link in the economy of a country, so this indicator has been chosen to describe the impact that floods can have on Romania's economy. Railways are considered one of the cheapest means of transport when it comes to transporting different goods/merchandise. An analysis made after finalization of hazard and flood risk maps indicates that approximate $500 \mathrm{~km}$ of railways can be affected by floods.

Public roads along with shipping and railways complete the transport infrastructure. The implementation process of Phase 2 of the Floods Directive has taken into account national and European roads, county roads, communal roads and the street network.

For this analysis, they were used the results for three categories of roads mentioned before. Thus, there is a risk of flooding about $311 \mathrm{~km}$ of national/European road, about $612 \mathrm{~km}$ of county road and about $434 \mathrm{~km}$ of communal road.

The effects that floods have on cultural heritage are another consequence that the Floods Directive imposes to the Member States to assess. Thus, in the analysed area, about 217 churches, 9 museums and 2 cultural monuments which can be flooded in the event of floods with a return period every 100 years, have been identified.

The centralized situation with the statistical indicators (key indicators) determined for the four categories of consequences established in accordance with the Floods Directive, in the case of the average scenario, respectively events with average probability (every 100 years), is presented in Table 4 .

\subsection{Climate change impact estimation on flood risk}

Until now, the methodology for estimating variations at 6 hours' time step of precipitation and temperatures as well as the maximum discharges from the future 
period compared to the reference period was applied to 6 river basins in Romania, among which the Crişul Alb river basin and the Mureş river basin from the Tisza basin.

Table 4. Statistical risk indicators

\begin{tabular}{|l|l|l|}
\hline $\begin{array}{c}\text { Consequences } \\
\text { categories }\end{array}$ & $\begin{array}{c}\text { Potential adverse } \\
\text { consequences }\end{array}$ & \multicolumn{1}{c|}{ Quantification (number/length/etc.) } \\
\hline Social & population & 376.252 exposed inhabitants \\
\hline Economic & infrastructure & $\begin{array}{l}500 \mathrm{~km} \text { railway, } 311 \mathrm{~km} \text { national/European road, } \\
612 \mathrm{~km} \text { county road, 434 km communal road }\end{array}$ \\
\hline Environment & protected areas & $\begin{array}{l}40 \text { areas SPA, } 46 \text { areas SCI, 66 protected areas } \\
\text { for water capture for human consumption, } 17 \\
\text { IED installations }\end{array}$ \\
\hline Cultural heritage & cultural objectives & 217 churches, 9 museums, 2 cultural monuments \\
\hline
\end{tabular}

In a first step, the comparative analysis of the results obtained for the two periods (the reference period and the future period) was performed for the maximum monthly instantaneous discharges, multiannual averages. The following results were obtained for the analysed river basins:

- the Crişul Alb river basin: an increase of maximum discharges in January, April, July, September and December and a decrease in the other months of the year;

- the Mureş river basin: an increase of maximum discharges in the winter months as well as in March and July and a decrease in the other months of the year.

For multiannual maximum discharges, the simulations indicated:

- the Crişul Alb river basin: decrease of about $-22.7 \%$ (between a minimum of $-35.0 \%$ and a maximum of $7.6 \%$ );

- the Mureş river basin: decrease of about $-11.3 \%$ (-39.0\% and $16.6 \%$ ).

With regard to the variation of maximum discharges with different probabilities of exceedance in sections of hydrometric stations on main river courses, the results are itemed below:

- Crişul Alb river basin: maximum discharges with probabilities of exceedance $0.1 \%, 1 \%, 2 \%, 5 \%$ and $10 \%$ have a decreasing trend of up-to $-14 \%$ in the upper zone and maximum $-10 \%$ in the lower zone;

- Mureş river basin: maximum discharges with probabilities of exceedance $0.1 \%, 1 \%, 2 \%, 5 \%$ and $10 \%$ have a decreasing trend of up to $-7 \%$ in the upper zone and maximum $-9 \%$ in the lower one, and a tendency of increase of up to $7 \%$ in the middle zone.

\section{CONCLUSIONS}

The first stage in the process of implementation of Directive 2007/60/EC on assessment and management of flood risk, was the preliminary flood risk assessment, which was due to be reported to the European Commission (in 22 
March 2012). The selection of significant historical floods has been made by applying the hydrological criteria and others for the adverse effects of the flood on the four categories of consequences set out in the directive: human health, environment, cultural heritage and economic activity.

In the second stage, hazard maps and flood risk maps (reported in 22 March 2014) have been drawn up for areas designated as having a significant potential flood risk were developed during the first stage of implementation.

The results were obtained under the National Programme for Prevention, Protection and Reduction of Flood Effects (PPPDEI), based on scientific/advanced methods of hydraulic modeling, and of some simplified methods of generating flood curves applied in areas not covered by PPPDEI.

Elaboration of flood risk maps was based on flood hazard maps and analysis of data on the elements exposed to the hazard and their vulnerability.

These two phases were the basis for the third reporting one, respectively the development of Flood Management Plans on river basins (in 22 March 2016).

\section{ACKNOWLEDGEMENTS}

This flood risk assessment at Tisa river basin level has been made into the JOINTISZA project which is developing beginning with 1 January 2017 til 30 June 2019 under Danube Transnational Programme (DTP) - financing instrument of the European Territorial Cooperation (ETC), better known as INTERREG and having as main output the second Integrated Tisza River Basin Management Plan. The data was provided by the National Institute of Hydrology and Water Management and the "Romanian Waters" National Administration.

\section{REFERENCES}

1. Corbuș C., Mic, R., Mătreaţă, M. (2011) Assessment of climate change impact on peak flow regime in the Mureş river basin. $\mathrm{XXV}^{\text {th }}$ conference of Danubian countries, 16-17 June, Budapest, Hungary

2. Corbuş, C., Mic, R.P., Mătreaţă, M., Chendeş, V. (2012) Climate change impact upon maximum flow in Siret river basin. $12^{\text {th }}$ international multidisciplinary scientific geoconference SGEM 2012, conference proceedings, volume III, Albena, Bulgaria, 587-594

3. Corbuş, C., Mic, R.P., Mătreață, M. (2013) Potential climate change impact upon maximum flow in Ialomita river basin. National Institute of Hydrology and Water Management - scientific conference, "Water resources management under climate and anthropogenic changes", 23-26 September, Bucharest

4. Corbuș, C., Mic, R.P., Mătreață, M. (2014) Estimarea impactului schimbărilor climatice potenţiale asupra scurgerii maxime din bazinul hidrografic Olt Revista Hidrotehnica 59 (10-11), 28-38

5. Leonte-Neagu, E., Corbuş, C., Mătreaţă, M., Simota, M. (1997) Elaboration of some continuous forecasting models of discharges (floods, daily and monthly mean 
discharges) in the river basin Dâmboviţa, (in Romanian). Collection of papers presented at the seminar ARDI, January 31, National Institute of Meteorology and Hydrology, Bucharest, 46-58

6. Mic, R., Corbus, C., Pescaru, V.I., Velea, L. (2006) Coupling the hydrologic model CONSUL and the meteorological model HRM in the Crisul Alb and Crisul Negru river basins. Transboundary Floods: Reducing Risks Through Flood Management, 69-77.

7. Stanciu P, Nedelcu G, Nicula G (2005) Hazardurile hidrologice din Romania. Nat Anthropog Hazards 5(23):11-17

8. Stanescu, V. Al. \& Matreata, M. (1997) Large floods in Europe. In: FRIENDFlow Regimes from International Experimental and Network Data, Third report: 19941997. Cemagref Editions, Antony, France.,

9. $* * *$ Flood risk management plans for Someș-Tisa, Crișuri, Mureș and Banat river basins.

10. *** Hydrological studies from the National Institute of Hydrology and Water Management.

11. *** National Programme for Prevention, Protection and Reduction of Flood Effects (PPPDEI).

12. *** JoinTisza Project - Application Form submitted in 2016 \& Romanian reports.

13. $* * *$ www.rowater.ro 